\title{
Metal Uptake by Sunflower (Helianthus annuus) Irrigated with Water Polluted with Chromium and Nickel
}

\author{
Vasiliki Stoikou ${ }^{1}$, Vangelis Andrianos ${ }^{1}$, Sotiris Stasinos ${ }^{1}$, Marios G. Kostakis ${ }^{2}$, Sofia Attiti ${ }^{2}$, \\ Nikolaos S. Thomaidis ${ }^{2}$ (D) and Ioannis Zabetakis ${ }^{1,3, *}$ \\ 1 Laboratory of Food Chemistry, Department of Chemistry, University of Athens, 15771 Athens, Greece; \\ vstoikou@chem.uoa.gr (V.S.); vandrianos@chem.uoa.gr (V.A.); sstas@teemail.gr (S.S.) \\ 2 Laboratory of Analytical Chemistry, Department of Chemistry, University of Athens, 15771 Athens, Greece; \\ makostak@chem.uoa.gr (M.G.K.); sofia-attiti@chem.uoa.gr (S.A.); ntho@chem.uoa.gr (N.S.T.) \\ 3 Department of Biological Sciences, University of Limerick, V94 T9PX Limerick, Ireland \\ * Correspondence: ioannis.zabetakis@ul.ie; Tel.: +353-61-234202; Fax: +353-61-331490
}

Received: 14 June 2017; Accepted: 13 July 2017; Published: 17 July 2017

\begin{abstract}
The water aquifers of the regions of Asopos River in Viotia and Messapia in Evia (Greece) have been contaminated with hexavalent chromium ( $\mathrm{Cr}(\mathrm{VI})$ ) and bivalent nickel (Ni (II)). Given that these areas are the two biggest tuber producing regions of Greece, in our previous work, the cross-contamination of the food chain with these two heavy metals was quantified. In the present study, the potential of sunflower (Helianthus annuus) cultivation in these regions is evaluated. The scope of our study was to investigate the uptake of chromium and nickel by sunflower, in a greenhouse experiment. The study included two cultivation periods of plants in six irrigation lines with different levels of $\mathrm{Cr}(\mathrm{VI})$ and $\mathrm{Ni}$ (II) ranging from $0 \mu \mathrm{g} / \mathrm{L}$ (control) to 10,000 $\mu \mathrm{g} / \mathrm{L}$. In all plant parts, statistically significant increased levels of $\mathrm{Cr}$ (VI) and $\mathrm{Ni}$ (II) were found when compared to control ones. Also, a positive correlation, both for $\mathrm{Cr}$ and $\mathrm{Ni}$, between levels of heavy metals in irrigation water and plants was observed. Following European Food Safety Authority recommendations, the obtained oil was evaluated as safe for consumption, therefore, sunflower cultivation could be a valid bioremediation solution for the Asopos and Messapia regions.
\end{abstract}

Keywords: chromium; nickel; sunflower; sunflower oil; metal uptake; water; safety

\section{Introduction}

Asopos River in Viotia and Messapia in Evia are the two main tuber (i.e., carrot, potato, and onion) producing regions in Greece. The water aquifer of both areas is polluted with heavy metals due to proximate industrial and mining activities. As a result, the irrigation water used in the food production is contaminated with hexavalent Chromium (Cr (VI)) and bivalent Nickel (Ni (II)). In a greenhouse experiment simulating the irrigation parameters of these regions, it was found that both $\mathrm{Cr}$ and $\mathrm{Ni}$ (present in irrigation water) can cross-contaminate the food tubers [1]. This cross-contamination also affects the nutritional value of food products [2].

Phytoextraction is a remediation green technology that uses plants to remove, reduce, degrade, or immobilize heavy metals from polluted soil and water. As a remediation technology, it takes advantage of the ability of plants to concentrate elements and compounds from the environment and to metabolize various molecules in their tissues. The success of a phytoextraction process depends on sufficient plant yield (aerial parts) and high metal concentrations in plant parts [3]. Water pollution with heavy metals has been a worldwide concern, as it poses great threats to crop production causing significant cross-contamination of the food chain [4], resulting in negative impacts on human health [5]. 
As an emerging green technology, phytoextraction has increasingly received widespread attention [6]. The success depends on the growth stage, during which biomass production and accumulation is more intense [7]. The choice of the appropriate method of remediation is governed by the mobility, distribution, and speciation of the toxic metals in soils and plants.

A variety of anthropogenic factors can be responsible for heavy metal pollution in soils. Heavy metals are very persistent in the environment, they do not biodegrade or thermodegrade, and they accumulate to toxic levels. The cross-contamination of food by $\mathrm{Ni}$ and $\mathrm{Cr}$ is an emerging nutritional hazard [8]. Although $\mathrm{Ni}$ is an essential metal and plays important roles in plant metabolism, Ni toxicity has become of particular concern due to its increased industrial use [9]. More specifically, nickel in high doses and certain forms is toxic and is known to be a human carcinogen, targeting human body systems such as cardiovascular, dermal, immunological, and respiratory. Meanwhile, chromium is of special interest because it is both an essential nutrient and a carcinogen. Chromium is an essential trace element in the human diet. It is poorly absorbed, and the concentrations of chromium in various tissues and fluids are normally quite low. There is no conclusive evidence yet of an essential role of $\mathrm{Cr}$ in plant metabolism. Some plant species can accumulate relatively large amounts of the element in their shoots. These are termed as 'Cr accumulators' [10].

Sunflower (Helianthus annuus) is cultivated as a food and feed crop as well as for bioenergy production, and it has an important role as a plant. It is also being investigated for its ability to remove contaminants from soil. Sunflower can accumulate $\mathrm{Pb}, \mathrm{Cu}$, and $\mathrm{Cd}$ in the shoots [6]. Sunflower's shoots and roots exhibited the highest $\mathrm{Co}$ and $\mathrm{Cr}$ uptake compared to other tested species in any investigated soil. The time required for remediation depends on the type of the metal, the extent of metal pollution, and the length of growing season [11]. Sunflowers were also screened for their capacity to tolerate different concentrations of chromium, hexavalent $\mathrm{Cr}$ (VI), and trivalent $\mathrm{Cr}$ (III). Sunflower, due to its big biomass, is also recommended for rhyzofiltration and phytoremediation purposes [12]. Studies have reported that the effects of reductants on $\mathrm{Cr}$ (VI) phytoremediation clearly influenced $\mathrm{Cr}$ concentrations in the roots and shoots of plant Ipomoea aquatica. The applications of $\mathrm{S}_{2} \mathrm{O}_{3}{ }^{2-}, \mathrm{Fe}^{0}$, and $\mathrm{Fe}^{2+}$ at low doses notably increased root $\mathrm{Cr}$ concentrations. However, high reductant concentrations decreased bioaccumulation of $\mathrm{Cr}$ in the roots and shoots of the plant [13]. Excess $\mathrm{Ni}$ has been reported to cause leaf necrosis and chlorosis of plants. The uptake of Ni by plants depends on $\mathrm{Ni}^{2+}$ concentrations, plant metabolism, the acidity of soil or solution, the presence of other metals, and organic matter composition [9]. Helianthus annuus which was grown in a soil substrate to which nickel was introduced at 25,50,75, and $150 \mathrm{mg} / \mathrm{kg}$, accumulated the highest amounts of this metal. For sunflowers grown on a former uranium mining site, 140-170 days of growth were found to be optimal to reach a maximum extraction for all 25 investigated elements $(\mathrm{Cd}, \mathrm{Co}, \mathrm{Cr}, \mathrm{Cu}, \mathrm{Fe}, \mathrm{Mn}, \mathrm{Ni}, \mathrm{Pb}$, $\mathrm{Th}, \mathrm{U}, \mathrm{Zn}$, and rare earth elements) [14].

Given the polluted water aquifers in the tuber producing areas in Greece, this study aimed to evaluate the potential of sunflower, as a $\mathrm{Cr}$ and $\mathrm{Ni}$ phytoaccumulator, in order to give an alternative farming suggestion. Our working hypothesis was that $\mathrm{Cr}$ and $\mathrm{Ni}$, given their hydrophilic character, would not accumulate in lipid fractions of sunflower oil. With our work, reported here, we studied the uptake of $\mathrm{Cr}$ and $\mathrm{Ni}$ by roots, shoots, leaves, and blossoms of Helianthus annuus and assessed the levels of $\mathrm{Cr}$ and $\mathrm{Ni}$ in the obtained sunflower oil.

\section{Materials and Methods}

\subsection{Plant Cultivation in a Greenhouse}

Seeds of Helianthus annuus were collected from a local agricultural centre, and for the purposes of this study, six irrigation lines (i.e., six 300 L plastic tanks, six pumps, and six series of three tubs per series) were constructed in a greenhouse in the Department of Chemistry at Athens University, Greece. The first cultivation period was from March to July 2015 where the sunflowers were planted in soil and then irrigated by water containing different levels of $\mathrm{Cr}$ (VI) and Ni (II), prepared by 
solid $\mathrm{K}_{2} \mathrm{Cr}_{2} \mathrm{O}_{7}$ and $\mathrm{NiCl}_{2} \cdot 6 \mathrm{H}_{2} \mathrm{O}$, respectively. The six lines carried risk elements as follows: $0 \mu \mathrm{g} / \mathrm{L}$ (control), $100 \mu \mathrm{g} / \mathrm{L}, 500 \mu \mathrm{g} / \mathrm{L}, 1000 \mu \mathrm{g} / \mathrm{L}, 5000 \mu \mathrm{g} / \mathrm{L}$, and 10,000 $\mu \mathrm{g} / \mathrm{L}$ in tap water solutions of both $\mathrm{Cr}$ (VI) and Ni (II). All the plants were fertilized as described before [1]. The values of the main physicochemical parameters of control (tap) water were: $\mathrm{pH}=8.3$, turbidity $=7.6 \mathrm{NTU}$, electrical conductivity $(\mathrm{EC})=295 \mu \mathrm{S} / \mathrm{cm}$, total dissolved solids $(\mathrm{TDS})=156 \mathrm{mg} / \mathrm{L}, \mathrm{Na}=4.6 \mathrm{mg} / \mathrm{L}, \mathrm{K}=0.8 \mathrm{mg} / \mathrm{L}$, $\mathrm{Pb}=0.3 \mu \mathrm{g} / \mathrm{L}, \mathrm{Hg}=0 \mu \mathrm{g} / \mathrm{L}, \mathrm{Cd}=0 \mu \mathrm{g} / \mathrm{L}, \mathrm{Cr}=0 \mu \mathrm{g} / \mathrm{L})$. The physicochemical properties of the soil used were determined as: $\mathrm{pH}=8.2 \pm 0.1$, conductivity $=2.89 \pm 0.33 \mathrm{mS} / \mathrm{cm}, \mathrm{CaCO}_{3}=9.49 \pm 0.58$ percent, organic matter $=1.91 \pm 0.35$ percent, and the grain composition of soil was: sand $=38.6 \pm 1.9$ percent, clay $=5.9 \pm 1.1$ percent, and sludge $=55.4 \pm 2.3$ percent. The soil was characterized as silt-clayey.

Plants were harvested as a whole and carefully separated into four different parts with a stainless steel cutter. On average, six sunflowers per tub were taken and separated to roots, shoots, leaves, and blossoms, and each part was sliced into very small pieces with a knife. Afterwards, roots, shoots, leaves, and blossoms were separately dried at $40{ }^{\circ} \mathrm{C}$.

A representative quantity of $8-10 \mathrm{~g}$ per plant was weighed and put in plastic vessels, refrigerated for $24 \mathrm{~h}$ in $-80{ }^{\circ} \mathrm{C}$, freeze dried in $-55^{\circ} \mathrm{C}$ and -1 bar pressure for $48 \mathrm{~h}$, and pulverized by mortar and pestle. Samples of $0.5 \mathrm{~g}$ per pulverized plant were diluted in $5 \mathrm{~mL}$ of suprapure $\mathrm{HNO}_{3}$ (65 percent $v / v), 1 \mathrm{~mL}$ of $\mathrm{H}_{2} \mathrm{O}_{2}$, and microwave digested in a three step digestion program $\left(150{ }^{\circ} \mathrm{C}\right.$ for $7 \mathrm{~min}$, $170{ }^{\circ} \mathrm{C}$ for $10 \mathrm{~min}, 180^{\circ} \mathrm{C}$ for $10 \mathrm{~min}$ ). After digestion, each sample was diluted to $20 \mathrm{~mL}$ final volume by distilled water. Blank samples containing only suprapure nitric acid and hydrogen peroxide and samples containing Standard Reference Material NIST 1573a (tomato leaves) were also digested and analyzed to verify the credibility of the analysis.

The second cultivation period was from March 2016 to July 2016, following the same methodology and irrigation lines. Blossoms were harvested as a whole and carefully separated from seeds. Afterwards, seeds were dried at $40{ }^{\circ} \mathrm{C}$ followed by grinding and extraction with hexane in order to extract the oil. Oil samples were diluted in $5 \mathrm{~mL}$ suprapure $\mathrm{HNO}_{3}(65$ percent $v / v)$ and $1 \mathrm{~mL}$ of $\mathrm{H}_{2} \mathrm{O}_{2}$ and microwave digested in a three step digestion program as above. After digestion, each sample was diluted to $20 \mathrm{~mL}$ final volume by distilled water. Oil market samples were also analyzed.

For each cultivation period (March-July 2015 and March-July 2016), each tub was totally irrigated with about $750 \mathrm{~L}$ of water with $\mathrm{Cr}$ (VI) and $\mathrm{Ni}$ (II) concentrations varying from 0 to $10,000 \mu \mathrm{g} / \mathrm{L}$. The total mass of $\mathrm{Cr}$ (VI) and $\mathrm{Ni}$ (II) added in each tub for the irrigation watering lines of 0, 100, 500, 1000,5000 , and 10,000 $\mu \mathrm{g} / \mathrm{L}$ was $0,75,375,750,3750$, and $7500 \mathrm{mg}$, respectively. During the whole period of the experiment, no symptoms of toxicity were observed in any plant.

For Cr: average concentration of total $\mathrm{Cr}$ was $127.7 \pm 2.7 \mathrm{mg} / \mathrm{kg}$ before the first cultivation and $129.1 \pm 2.6 \mathrm{mg} / \mathrm{kg}$ after the first cultivation; $129.1 \pm 2.6 \mathrm{mg} / \mathrm{kg}$ before the second cultivation and $129.9 \pm 2.6 \mathrm{mg} / \mathrm{kg}$ after the second cultivation. For Ni: average concentration of $\mathrm{Ni}$ was $162.0 \pm 5.3 \mathrm{mg} / \mathrm{kg}$ before the first cultivation and $162.9 \pm 5.2 \mathrm{mg} / \mathrm{kg}$ after the first cultivation; $162.9 \pm 5.2 \mathrm{mg} / \mathrm{kg}$ before the second cultivation and $163.7 \pm 5.3 \mathrm{mg} / \mathrm{kg}$ after the second cultivation.

Each tub contained $500 \mathrm{~kg}$ of soil and the maximum levels of metals added to the soil, i.e., irrigation watering line of $10,000 \mu \mathrm{g} / \mathrm{mL}$, were $7500 \mathrm{mg}$ or $15 \mathrm{mg} / \mathrm{kg}$. As discussed in our previous work [1], the $\mathrm{Cr}$ and $\mathrm{Ni}$ quantities added in soil are relatively small in relation to the existing levels of $\mathrm{Cr}$ and $\mathrm{Ni}$ already present in the soil. In other words, there are already considerable natural "background" levels of both metals in the soil, before irrigation with $\mathrm{Cr}$ and $\mathrm{Ni}$ polluted water [1]. This is the reason that the soil levels of $\mathrm{Cr}$ and $\mathrm{Ni}$ have not been increased during the irrigation experiments. It could be thus suggested that irrigated heavy metals were either absorbed by the plants or depleted.

\subsection{Reagents and Instrumentation}

The materials used for $\mathrm{Cr}$ and $\mathrm{Ni}$ determination were, nitric acid (65 percent $v / v$, suprapure grade from Merck, Darmstadt, Germany), hydrogen peroxide $\left(\mathrm{H}_{2} \mathrm{O}_{2}\right)$, ultrapure water (Millipore, Cork, Ireland, MilliQ), Standard Reference Material NIST 1573a (tomato leaves, from National Institute of Standard and Technology for plants analysis), and commercially available sunflower oil samples. 
The instrument used for elemental determination in roots, shoots leaves, blossoms, and oils was a Perkin Elmer SIMAA6000 simultaneous multi-elemental atomic absorption spectrometer with THGA graphite furnace and a Zeeman background corrector. The digestions were performed in a microwave oven MARS X Press. The certified mass fractions by National Institute of Standard and Technology (NIST) Of Standard Reference Material 1573a (tomato leaves), for $\mathrm{Cr}$ and Ni were estimated $1.99 \pm 0.06$ and $1.59 \pm 0.07 \mu \mathrm{g} / \mathrm{g}$, respectively. The $\mathrm{Cr}$ and Ni concentrations of Standard Reference Material for plants NIST1573A (tomato leaves) in our experiment were measured as $1.65 \pm 0.37 \mu \mathrm{g} / \mathrm{g}$ and $1.39 \pm 0.72 \mu \mathrm{g} / \mathrm{g}$ plant dry matter $(n=13)$ indicating that the results were reliable.

\subsection{Gas Chromatographic Analysis of Fatty Acids in Sunflower Oil}

\subsubsection{Reagents and Instruments}

All reagents and solvents were of analytical grade purchased from Merck (Darmstadt, Germany). Fatty acid methyl ester standards were of Gas Chromatography (GC)-quality and supplied by Sigma-Aldrich (St. Louis, MO, USA).

\subsubsection{Gas Chromatographic Analysis}

Fatty acid methyl esters (FAME) of $35 \mathrm{mg}$ of all oil samples were prepared using a solution of $0.5 \mathrm{~N} \mathrm{KOH}$ in $\mathrm{CH}_{3} \mathrm{OH}\left(\mathrm{KOH}-\mathrm{CH}_{3} \mathrm{OH}\right.$ method, reaction time $\left.5 \mathrm{~min}\right)$ and extracted with $n$-hexane. The fatty acid analysis was carried out using the internal standard method [15]. A 5-point calibration curve was prepared using five solutions of heptadecanoic (17:0) acid methyl ester and heneicosanoic $(21: 0)$ acid methyl ester in ratios of 500:1000 $(v / v), 500: 500(v / v), 500: 200(v / v), 500: 100(v / v)$, and 500:50 $(v / v)$, respectively. Five injections of $1 \mu \mathrm{L}$ of each solution were analyzed with a Shimadzu CLASS-VP (GC-17A, Kyoto, Japan) gas chromatograph equipped with a split/splitless injector and flame ionization detector. The ratio of the mean area (21:0) to that of the internal standard (17:0) was used as the $y$-axis variable of the calibration curve, while the concentration $\left(\mathrm{mg} \mathrm{kg}^{-1}\right)$ of 21:0 was used as the $x$-axis variable of the calibration curve. The equation that described the calibration curve was: $y=0.0012 x+0.0210$, with $r=0.996$. The ratio of the area of the analyte peak to that of the internal standard represents the $y$ value at the above equation, and subsequently the $x$ value represents the analyte concentration of the fatty acid in the unknown mixture. Separation of fatty acid methyl esters was achieved on an Agilent J\&W DB-23 fused silica capillary column $(60 \mathrm{~m} \times 0.251 \mathrm{~mm}$ i.d., $0.25 \mu \mathrm{m}$; Agilent, Santa Clara, CA, USA). The oven temperature program was: initially $120^{\circ} \mathrm{C}$ for $5 \mathrm{~min}$, raised to $180{ }^{\circ} \mathrm{C}$ at $10^{\circ} \mathrm{C} \mathrm{min}^{-1}$, then to $220^{\circ} \mathrm{C}$ at $20^{\circ} \mathrm{C} \mathrm{min}^{-1}$, and finally isothermal at $220^{\circ} \mathrm{C}$ for $30 \mathrm{~min}$. The injector and detector temperatures were maintained at 220 and $225^{\circ} \mathrm{C}$, respectively. The carrier gas was high purity helium with a linear flow rate of $1 \mathrm{~mL} \mathrm{~min}^{-1}$ and split ratio 1:50. Fatty acid methyl esters were identified using FAME standards as described previously [15].

\subsection{Statistical Methodology}

The results were statistically processed with IBM SPSS 23 (SPSS Inc., Chicago, IL, USA) and the figures were produced using STATACORP Stata 13 (StataCorp., College Station, TX, USA). The distributions of values diverged from the normal distribution, as shown by the relevant graphic control PP plot in SPSS 23. The levels of $\mathrm{Cr}$ and $\mathrm{Ni}$ in plants have been calculated as the median values. The statistical evaluation of the differences of $\mathrm{Cr}$ and $\mathrm{Ni}$ levels between the water concentrations of $0 \mu \mathrm{g} / \mathrm{L}$ and $100 \mu \mathrm{g} / \mathrm{L}, 500 \mu \mathrm{g} / \mathrm{L}, 1000 \mu \mathrm{g} / \mathrm{L}, 5000 \mu \mathrm{g} / \mathrm{L}$, and 10,000 $\mu \mathrm{g} / \mathrm{L}$ was based on the Mann-Whitney non-parametric control. The same non-parametric test was implemented for the "two by two" comparisons between the concentrations of the two heavy metals $(\mathrm{Cr}, \mathrm{Ni})$ in irrigation water, while Bonferroni and Sidak corrections were used for the correction of the influence of multiple comparisons (increase of "type I" error) [16]. The non-parametric rank correlation coefficient of Spearman (rho) was also used for the investigation of the relationship between the levels of $\mathrm{Cr}$ and $\mathrm{Ni}$ in different plants, separately for every metal's concentration in irrigation water. In order to 
approximate the association between $\mathrm{Cr}$ and $\mathrm{Ni}$ within each plant, as well as between each of these heavy metals and the corresponding concentration in the irrigation water, locally weighted scatter plot smoothing (Lowess) was used. The limit of statistical significance was 0.05 . When $\mid$ rho $\mid>0.3$ and $p$-value $<0.05$, then the relationship is statistically significant. One-way analysis of variance (ANOVA) using the Office Excel 2010, was used in order to find the statistically significant differences between the fatty acids in oil samples in different irrigation water lines. Differences were considered to be statistically significant when the $p$-value was lower than 0.05 .

\section{Results}

\subsection{Levels of $\mathrm{Cr}$ and $\mathrm{Ni}$ in Different Plant Parts}

In shoots, the highest $\mathrm{Cr}$ absorption was observed in the 10,000 $\mu \mathrm{g} / \mathrm{L}$ irrigation line $(6.011 \mu \mathrm{g} / \mathrm{g}$ dry matter). In blossoms, the maximum $\mathrm{Cr}$ absorption was measured in the $500 \mu \mathrm{g} / \mathrm{L}$ and the $10,000 \mu \mathrm{g} / \mathrm{L}$ irrigation lines (3.142 and $3.087 \mu \mathrm{g} / \mathrm{g}$ dry matter, respectively). Chromium in leaves in the $10,000 \mu \mathrm{g} / \mathrm{L}$ irrigation line was measured at $16.78 \mu \mathrm{g} / \mathrm{g}$ dry matter and it was 2.79 times higher than $\mathrm{Cr}$ absorbance in shoots. It should also be noted that $\mathrm{Cr}$ in sunflower leaves has been measured in amounts greater than $2 \mu \mathrm{g} / \mathrm{g}$ [17]. While chromium toxicity studies in plants (especially spinach) suggest that the leaves have reduced growth, browning, and chlorosis [18], in our experiment, the sunflower leaves showed very limited browning. For roots, the maximum absorption of $\mathrm{Cr}$ was observed in the $5000 \mu \mathrm{g} / \mathrm{L}$ irrigation line (and not in the 10,000 $\mu \mathrm{g} / \mathrm{L}$ irrigation line) $\left(14.76 \times 10^{2} \mu \mathrm{g} / \mathrm{g}\right.$ dry matter) (Supplementary Materials Figure S1). This could be explained on the basis that the highest levels of heavy metals in water may have caused minor phytotoxic effects to the plants that reduced the absorption of heavy metals. These results are in agreement with our previous work on food tubers [1]. The largest amount of chromium appears to accumulate in sunflower roots. Despite this fact, the roots showed no toxicity, chlorosis, or necrosis after exposure to chromium and nickel, compared to the roots of control plants $(0 \mu \mathrm{g} / \mathrm{L})$. The Ni levels in shoots, leaves, and roots were higher in tubs obtained from the 10,000 $\mu \mathrm{g} / \mathrm{L}$ irrigation line, measured as $10.73 \mu \mathrm{g} / \mathrm{g}$ dry matter, $11.01 \mu \mathrm{g} / \mathrm{g}$ dry matter, and $127.7 \mu \mathrm{g} / \mathrm{g}$ dry matter, respectively). Blossoms showed highest nickel absorption in the $5000 \mu \mathrm{g} / \mathrm{L}$ irrigation line, measuring at $8.606 \mu \mathrm{g} / \mathrm{g}$ dry matter, suggesting that the highest levels of heavy metals in water may have been phytotoxic for the sunflower plants [1].

\section{2. "Two by Two" Comparisons}

The statistical significances ( $p$-values) of the differences in the levels of chromium and nickel in the "two by two" comparisons between $0 \mu \mathrm{g} / \mathrm{L}$ and $100 \mu \mathrm{g} / \mathrm{L}, 500 \mu \mathrm{g} / \mathrm{L}, 1000 \mu \mathrm{g} / \mathrm{L}, 5000 \mu \mathrm{g} / \mathrm{L}$, and $10,000 \mu \mathrm{g} / \mathrm{L}$ have been measured; Bonferroni and Sidak corrections were used for the correction of the influence of multiple comparisons and the corrected levels of statistical significance are given in Supplementary Table S1 ( ${ }^{*}$ level of significance $p=0.01$ (Bonferroni correction), \# level of significance $p=0.102062$ (Sidak correction)).

For roots, statistically significant differences in the $\mathrm{Cr}$ levels were observed between concentrations of $0 \mu \mathrm{g} / \mathrm{L}$ and $100 \mu \mathrm{g} / \mathrm{L}, 500 \mu \mathrm{g} / \mathrm{L}, 1000 \mu \mathrm{g} / \mathrm{L}$, and $5000 \mu \mathrm{g} / \mathrm{L}$; while no statistically significant differences in levels of Ni were observed in concentrations between $0 \mu \mathrm{g} / \mathrm{L}$ and $500 \mu \mathrm{g} / \mathrm{L}$ or $1000 \mu \mathrm{g} / \mathrm{L}$. Statistically indicative differences in Ni levels were observed in the roots between $0 \mu \mathrm{g} / \mathrm{L}$ and $5000 \mu \mathrm{g} / \mathrm{L}$. Statistically significant differences in the $\mathrm{Cr}$ levels were observed between concentrations of $100 \mu \mathrm{g} / \mathrm{L}$ and $500 \mu \mathrm{g} / \mathrm{L}, 1000 \mu \mathrm{g} / \mathrm{L}$, and $5000 \mu \mathrm{g} / \mathrm{L}$; while no statistically significant differences in Ni levels were found between concentrations of $100 \mu \mathrm{g} / \mathrm{L}$ and $1000 \mu \mathrm{g} / \mathrm{L}$. Statistically indicative differences in Ni levels were observed in concentrations between $100 \mu \mathrm{g} / \mathrm{L}$ and $5000 \mu \mathrm{g} / \mathrm{L}$. Statistically significant differences in the $\mathrm{Cr}$ levels were also noticed between concentrations of $500 \mu \mathrm{g} / \mathrm{L}$ and $1000 \mu \mathrm{g} / \mathrm{L}$ and $5000 \mu \mathrm{g} / \mathrm{L}$; while no statistically significant differences in Ni levels were found between concentrations of $500 \mu \mathrm{g} / \mathrm{L}$ and $5000 \mu \mathrm{g} / \mathrm{L}$. Statistically significant differences in the Cr levels were observed between concentrations of $1000 \mu \mathrm{g} / \mathrm{L}$ and $5000 \mu \mathrm{g} / \mathrm{L}$, while for Ni between $1000 \mu \mathrm{g} / \mathrm{L}$ and 
$10,000 \mu \mathrm{g} / \mathrm{L}$, no significant differences were noted. Statistically indicative differences in Cr levels were noticed between concentrations of $5000 \mu \mathrm{g} / \mathrm{L}$ and $10,000 \mu \mathrm{g} / \mathrm{L}$.

For shoots, statistically significant differences in the $\mathrm{Cr}$ levels were observed between concentrations of $0 \mu \mathrm{g} / \mathrm{L}$ and $500 \mu \mathrm{g} / \mathrm{L}, 1000 \mu \mathrm{g} / \mathrm{L}, 5000 \mu \mathrm{g} / \mathrm{L}$, and 10,000 $\mu \mathrm{g} / \mathrm{L}$; while no statistically significant differences in levels of Ni were observed between concentrations of $0 \mu \mathrm{g} / \mathrm{L}$ and $100 \mu \mathrm{g} / \mathrm{L}$. Statistically indicative differences in Ni levels were observed in the shoots between the concentrations $0 \mu \mathrm{g} / \mathrm{L}$ and $1000 \mu \mathrm{g} / \mathrm{L}$ and $5000 \mu \mathrm{g} / \mathrm{L}$. Statistically significant differences in the Cr levels were noticed between concentrations of $100 \mu \mathrm{g} / \mathrm{L}$ and $500 \mu \mathrm{g} / \mathrm{L}, 1000 \mu \mathrm{g} / \mathrm{L}, 5000 \mu \mathrm{g} / \mathrm{L}$, and 10,000 $\mu \mathrm{g} / \mathrm{L}$. Statistically indicative differences in Ni levels were observed between concentrations of $100 \mu \mathrm{g} / \mathrm{L}$ and $10,000 \mu \mathrm{g} / \mathrm{L}$. Statistically significant differences in the $\mathrm{Cr}$ levels were found between concentrations of $500 \mu \mathrm{g} / \mathrm{L}$ and $5000 \mu \mathrm{g} / \mathrm{L}$ and 10,000 $\mu \mathrm{g} / \mathrm{L}$; while the Ni levels were statistically significantly different between $500 \mu \mathrm{g} / \mathrm{L}$ and 10,000 $\mu \mathrm{g} / \mathrm{L}$. Statistically indicative differences in Ni levels were observed between concentrations of $500 \mu \mathrm{g} / \mathrm{L}$ and $5000 \mu \mathrm{g} / \mathrm{L}$. Statistically significant differences in the $\mathrm{Cr}$ and Ni levels were noticed between concentrations of $1000 \mu \mathrm{g} / \mathrm{L}$ and 10,000 $\mu \mathrm{g} / \mathrm{L}$. Statistically indicative differences in Ni levels were observed in the shoots between concentrations of $1000 \mu \mathrm{g} / \mathrm{L}$ and $5000 \mu \mathrm{g} / \mathrm{L}$. Statistically significant differences in the levels of $\mathrm{Cr}$ were shown between concentrations of $5000 \mu \mathrm{g} / \mathrm{L}$ and $10,000 \mu \mathrm{g} / \mathrm{L}$.

For leaves, statistically significant differences in the $\mathrm{Cr}$ levels were observed between the concentrations of $0 \mu \mathrm{g} / \mathrm{L}$ and $100 \mu \mathrm{g} / \mathrm{L}, 1000 \mu \mathrm{g} / \mathrm{L}$, and $5000 \mu \mathrm{g} / \mathrm{L}$; whereas no statistically significant differences in levels of Ni were noted between $0 \mu \mathrm{g} / \mathrm{L}$ and $500 \mu \mathrm{g} / \mathrm{L}, 1000 \mu \mathrm{g} / \mathrm{L}$, and $5000 \mu \mathrm{g} / \mathrm{L}$. Statistically indicative differences in Cr levels were observed between the concentrations of $0 \mu \mathrm{g} / \mathrm{L}$ and $500 \mu \mathrm{g} / \mathrm{L}$ and $10,000 \mu \mathrm{g} / \mathrm{L}$. Statistically significant differences in the $\mathrm{Cr}$ levels were observed between concentrations of $100 \mu \mathrm{g} / \mathrm{L}$ and $500 \mu \mathrm{g} / \mathrm{L}, 1000 \mu \mathrm{g} / \mathrm{L}, 5000 \mu \mathrm{g} / \mathrm{L}$, and 10,000 $\mu \mathrm{g} / \mathrm{L}$; while statistically significant differences in Ni levels were found between concentrations of $100 \mu \mathrm{g} / \mathrm{L}$ and $5000 \mu \mathrm{g} / \mathrm{L}$ and $10,000 \mu \mathrm{g} / \mathrm{L}$. Statistically significant differences in the $\mathrm{Cr}$ levels were observed between concentrations of $500 \mu \mathrm{g} / \mathrm{L}$ and $1000 \mu \mathrm{g} / \mathrm{L}$ and $5000 \mu \mathrm{g} / \mathrm{L}$, while for $\mathrm{Ni}$, such differences were observed between $500 \mu \mathrm{g} / \mathrm{L}$ and 10,000 $\mathrm{gg} / \mathrm{L}$. Statistically indicative differences in $\mathrm{Cr}$ levels were observed between concentrations of $500 \mu \mathrm{g} / \mathrm{L}$ and 10,000 $\mathrm{g} / \mathrm{L}$. Statistically significant differences in the $\mathrm{Cr}$ levels were also observed between concentrations of $1000 \mu \mathrm{g} / \mathrm{L}$ and $5000 \mu \mathrm{g} / \mathrm{L}$, while for Ni between $1000 \mu \mathrm{g} / \mathrm{L}$ and 10,000 $\mu \mathrm{g} / \mathrm{L}$, no significant differences were noted. Statistically significant differences in Ni levels were noticed between concentrations of $5000 \mu \mathrm{g} / \mathrm{L}$ and 10,000 $\mu \mathrm{g} / \mathrm{L}$, whereas statistically indicative differences in Cr levels were found between concentrations of $5000 \mu \mathrm{g} / \mathrm{L}$ and 10,000 $\mu \mathrm{g} / \mathrm{L}$.

For blossoms, no statistically significant differences in levels of $\mathrm{Cr}$ were observed between $0 \mu \mathrm{g} / \mathrm{L}$ and all irrigation water lines. Statistically indicative differences in $\mathrm{Ni}$ levels were observed between $0 \mu \mathrm{g} / \mathrm{L}$ and $1000 \mu \mathrm{g} / \mathrm{L}$ and $5000 \mu \mathrm{g} / \mathrm{L}$. Statistically indicative differences in $\mathrm{Cr}$ and Ni levels were observed between $100 \mu \mathrm{g} / \mathrm{L}$ and 10,000 $\mu \mathrm{g} / \mathrm{L}$; while statistically significant differences in the Ni levels were noticed between concentrations of $100 \mu \mathrm{g} / \mathrm{L}$ and $1000 \mu \mathrm{g} / \mathrm{L}$ and $5000 \mu \mathrm{g} / \mathrm{L}$. Statistically significant differences in the Ni levels were observed between concentrations of $500 \mu \mathrm{g} / \mathrm{L}$ and $1000 \mu \mathrm{g} / \mathrm{L}$ and $5000 \mu \mathrm{g} / \mathrm{L}$. Statistically significant differences in the $\mathrm{Cr}$ and Ni levels were also observed between concentrations of $1000 \mu \mathrm{g} / \mathrm{L}$ and $5000 \mu \mathrm{g} / \mathrm{L}$ and $10,000 \mu \mathrm{g} / \mathrm{L}$. 
Table 1. Levels of $\mathrm{Cr}$ and $\mathrm{Ni}$ in plants by concentration in irrigation water.

\begin{tabular}{|c|c|c|c|c|c|c|c|}
\hline \multicolumn{8}{|c|}{$\mathrm{Cr}(\mathrm{VI})$ and $\mathrm{Ni}(\mathrm{II})$ Concentration in Irrigation Water $(\mu \mathrm{g} / \mathrm{L})$} \\
\hline & 0 & 100 & 500 & 1000 & 5000 & 10,000 & \\
\hline & Median \pm SE & Median \pm SE & Median \pm SE & Median $\pm S E$ & Median \pm SE & Median \pm SE & rho $^{\text {a }}$ ( $p$-Value) \\
\hline Roots ${ }^{b}$ & & & & & & & \\
\hline Levels of $\mathrm{Cr}$ ( $\mu g / g$ dry matter $)$ & $0.1316 \times 10^{2} \pm 2.022$ & $0.3766 \times 10^{2} \pm 11.59$ & $3.041 \times 10^{2} \pm 39.63$ & $5.577 \times 10^{2} \pm 122.7$ & $17.99 \times 10^{2} \pm 547.0$ & $6.708 \times 10^{2} \pm 412.4$ & $0.945(0.000)$ \\
\hline $\begin{array}{c}\text { Levels of } \mathrm{Ni}(\mu \mathrm{g} / \mathrm{g} \text { dry matter }) \\
\text { Shoots }{ }^{\mathrm{c}}\end{array}$ & $0.1705 \times 10^{2} \pm 9.056$ & $0.1369 \times 10^{2} \pm 3.220$ & $0.5201 \times 10^{2} \pm 8.247$ & $0.2335 \times 10^{2} \pm 16.01$ & $0.5893 \times 10^{2} \pm 39.36$ & $1.085 \times 10^{2} \pm 83.49$ & $0.649(0.001)$ \\
\hline Levels of $\mathrm{Cr}(\mu \mathrm{g} / \mathrm{g}$ dry matter $)$ & $0.2250 \pm 0.2204$ & $0.1313 \pm 0.1071$ & $1.121 \pm 0.4430$ & $1.154 \pm 0.9477$ & $1.970 \pm 1.392$ & $4.000 \pm 3.641$ & $0.886(0.000)$ \\
\hline $\begin{array}{c}\text { Levels of } \mathrm{Ni}(\mu g / g \text { dry matter }) \\
\text { Leaves } \mathbf{d}\end{array}$ & $0.5715 \pm 0.2535$ & $0.4534 \pm 0.4782$ & $0.6328 \pm 0.2579$ & $0.2889 \pm 0.1083$ & $0.9707 \pm 0.8005$ & $4.954 \pm 9.772$ & $0.468(0.004)$ \\
\hline Levels of $\mathrm{Cr}(\mu \mathrm{g} / \mathrm{g}$ dry matter $)$ & $1.447 \pm 0.5481$ & $0.4819 \pm 0.0956$ & $2.218 \pm 0.7129$ & $4.057 \pm 1.127$ & $7.561 \pm 1.116$ & $0.1775 \times 10^{2} \pm 9.361$ & $0.817(0.000)$ \\
\hline $\begin{array}{c}\text { Levels of Ni ( } \mu g / g \text { dry matter }) \\
\text { Blossoms } \mathbf{e}^{\text {e }}\end{array}$ & $2.915 \pm 0.9664$ & $1.211 \pm 0.4430$ & $1.108 \pm 2.379$ & $2.292 \pm 2.399$ & $2.996 \pm 2.913$ & $0.1152 \times 10^{2} \pm 4.473$ & $0.482(0.003)$ \\
\hline Levels of $\mathrm{Cr}$ ( $\mu \mathrm{g} / \mathrm{g}$ dry matter) & $1.551 \pm 1.108$ & $1.331 \pm 1.952$ & $3.144 \pm 2.162$ & $1.133 \pm 0.6607$ & $2.087 \pm 0.7918$ & $2.271 \pm 1.700$ & $0.268(0.086)$ \\
\hline Levels of $\mathrm{Ni}$ ( $\mu \mathrm{g} / \mathrm{g}$ dry matter) & $5.236 \pm 2.418$ & $4.178 \pm 0.7036$ & $4.635 \pm 1.795$ & $2.047 \pm 0.5885$ & $7.966 \pm 2.588$ & $5.805 \pm 3.523$ & $0.293(0.057)$ \\
\hline
\end{tabular}

${ }^{\text {a }}$ Spearman's rank correlation coefficient while $p$-value is given in brackets; ${ }^{\mathrm{b}}\left(n=4\right.$ roots); ${ }^{\mathrm{c}}\left(n=6\right.$ shoots); ${ }^{\mathrm{d}}\left(n=6\right.$ leaves); ${ }^{\mathrm{e}}(n=6$ blossoms). 


\subsection{Spearman's Correlation}

The correlations between the levels of $\mathrm{Cr}$ and $\mathrm{Ni}$ within each part of the plant, for every irrigation water concentration, separately, are shown in Figure 1.

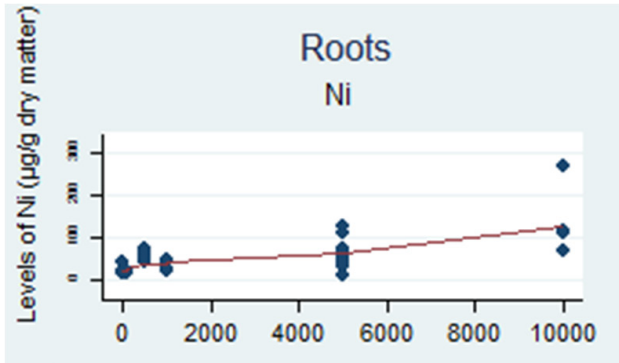

$\mathrm{Cr}(\mathrm{VI})$ and $\mathrm{Ni}(\mathrm{II})$ concentration in irrigation water $(\mu \mathrm{g} / \mathrm{l}$ Spearman's rho (p-value): $0,649(0,001)$
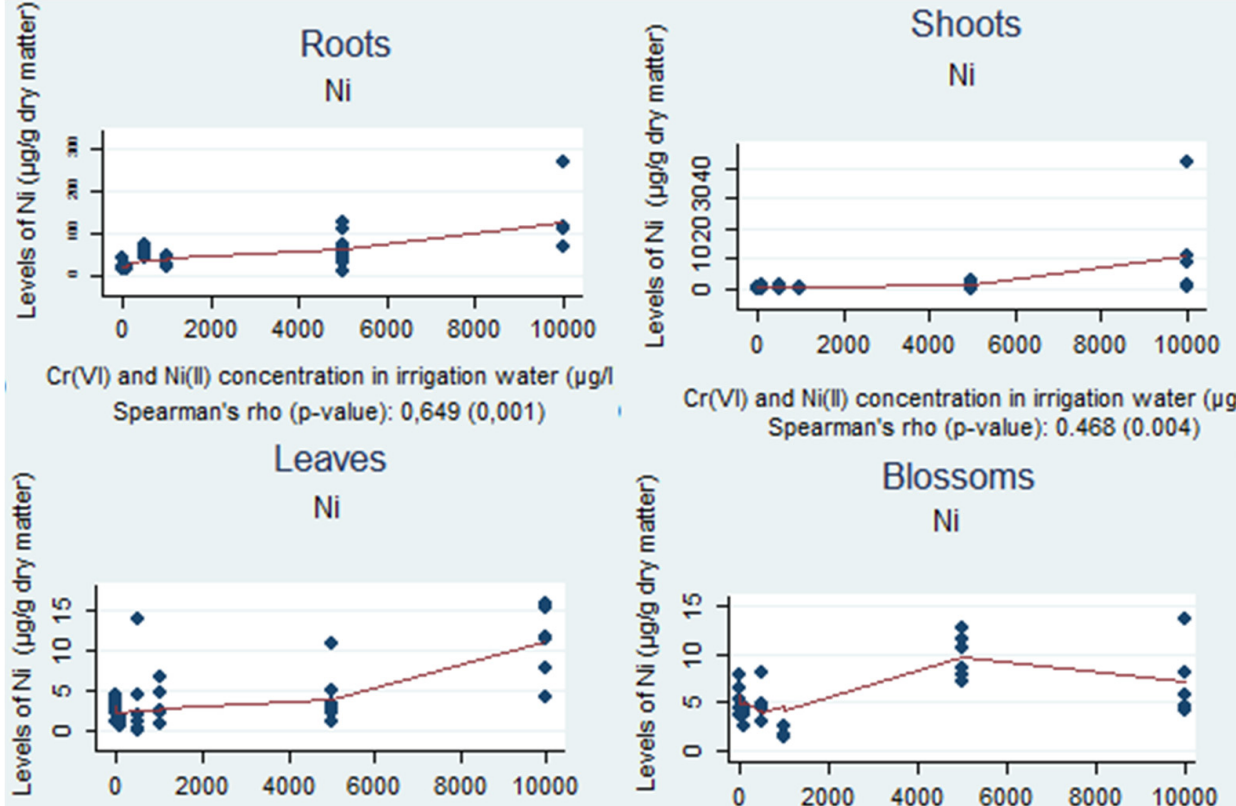

$\mathrm{Cr}(\mathrm{VI})$ and $\mathrm{Ni}(\mathrm{II})$ concentration in irrigation water $(\mu \mathrm{g} / \mathrm{l}$ Spearman's rho (p-value): $0.468(0.004)$

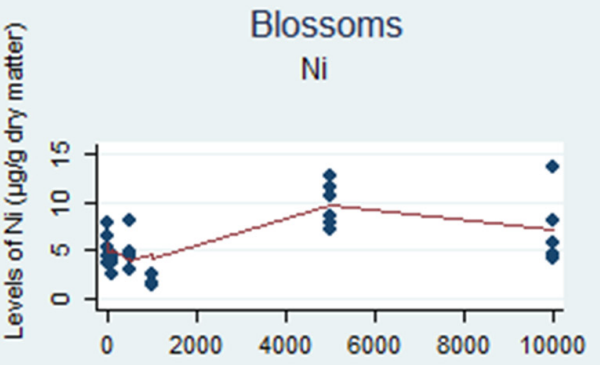

$\mathrm{Cr}(\mathrm{VI})$ and $\mathrm{Ni}(\mathrm{II})$ concentration in irrigation water $(\mu \mathrm{g} / \mathrm{l})$ $\mathrm{Cr}(\mathrm{VI})$ and $\mathrm{Ni}(\mathrm{Il})$ concentration in irrigation water $(\mu$ ! Spearman's rho (p-value): $0,482(0,003)$ Spearman's rho(p-value):0.293 (0.086)


$\mathrm{Cr}(\mathrm{VI})$ and $\mathrm{Ni}(\mathrm{II})$ concentration in irrigation water $(\mu \mathrm{g} / \mathrm{l})$
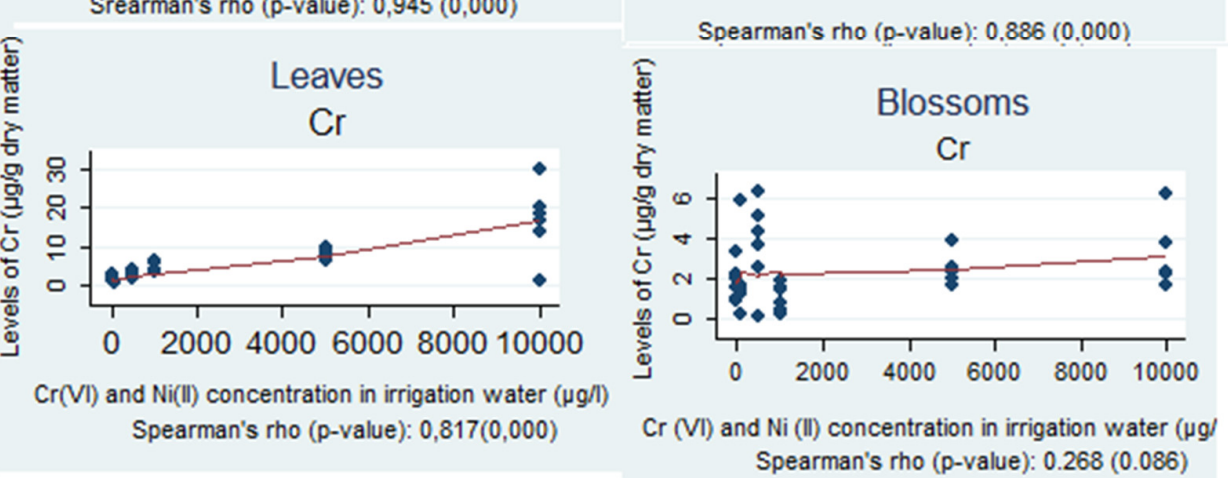

Figure 1. Correlations between the levels of chromium and nickel within each part of the plant, for every irrigation water concentration.

In Table 1, a positive correlation, characterized as statistical significance, between the levels of $\mathrm{Cr}$ and $\mathrm{Ni}$ in irrigation water and in roots, shoots and leaves is shown; the $p$-value was below the significance level and the non-parametric correlation coefficient was above 0.3 (Spearman's rho $>0.3$ ). 
In the sunflower roots, according to the statistical analysis, the correlation between the levels of $\mathrm{Cr}$ was very strong with Spearman's rho equal to 0.945 and the significance level ( $p$-value) equal to zero. In contrast to the above results, the correlation between $\mathrm{Ni}$ levels can be simply characterized as strong, since the non-parametric correlation coefficient, Spearman's rho, was 0.649 and the significance level ( $p$-value), was less than 0.05 .

In the shoots, Cr levels had a very strong correlation, since the non-parametric correlation coefficient, Spearman's rho, was 0.886 and the significance level ( $p$-value), was less than 0.05 . For $\mathrm{Ni}$ levels, the correlation can be characterized as moderate, because the non-parametric correlation coefficient (Spearman's rho) was 0.468 with a significance level ( $p$-value) of 0.004 .

In the leaves, the correlation between the $\mathrm{Cr}$ levels of the plant was also very strong with the non-parametric correlation coefficient (Spearman's rho) 0.817 and the significance level ( $p$-value) below 0.05 . For $\mathrm{Ni}$, the correlation can be categorized as moderate with Spearman's rho at 0.482 and $p$-value equal to 0.003 .

Finally, in the blossoms, the correlation between the levels of Cr was weak with Spearman's rho equal to 0.268 and the significance level ( $p$-value) was 0.086 , whereas for $\mathrm{Ni}$, the correlation can be simply characterized as weak, since the non-parametric correlation coefficient, Spearman's rho, was 0.293 and the significance level ( $p$-value) was 0.057 .

The correlations between $\mathrm{Cr}$ and $\mathrm{Ni}$ concentrations in roots, shoots, leaves, and blossoms, for all irrigation lines, are given in Table 2.

Table 2. Correlation $\mathrm{Cr}$ and $\mathrm{Ni}$ in shoots, leaves, blossoms, and roots by concentration in irrigation line.

\begin{tabular}{|c|c|c|c|c|c|c|}
\hline & \multicolumn{6}{|c|}{$\mathrm{Cr}(\mathrm{VI})$ and $\mathrm{Ni}(\mathrm{II})$ Concentration in Irrigation Water $(\mu \mathrm{g} / \mathrm{L})$} \\
\hline & 0 & 100 & 500 & 1000 & 5000 & 10,000 \\
\hline & rho $^{\text {a }}$ ( $p$-value) & rho $^{\text {a }}$ ( $p$-value) & rho $^{\text {a }}$ ( $p$-value) & rho $^{\text {a }}(p$-value $)$ & rho $^{\text {a }}(p$-value $)$ & rho ${ }^{\text {a }}(p$-value $)$ \\
\hline Roots $b$ & & & & & & \\
\hline $\begin{array}{l}\text { Levels of } \mathrm{Cr} / \mathrm{Ni} \\
\text { Shoots } \mathbf{c}\end{array}$ & $-0.200(0.800)$ & $0.200(0.800)$ & $0.000(1.000)$ & $0.400(0.600)$ & $0.400(0.600)$ & $0.400(0.600)$ \\
\hline $\begin{array}{c}\text { Levels of } \mathrm{Cr} / \mathrm{Ni} \\
\text { Leaves } \mathbf{d}\end{array}$ & $0.600(0.208)$ & $0.757(0.084)$ & $0.486(0.329)$ & $-0.143(0.787)$ & $-0.086(0.872)$ & $0.986(0.000)$ \\
\hline $\begin{array}{l}\text { Levels of } \mathrm{Cr} / \mathrm{Ni} \\
\text { Blossoms }\end{array}$ & $0.943(0.005)$ & $0.086(0.872)$ & $0.714(0.111)$ & $-0.086(0.872)$ & $-0.429(0.397)$ & $0.886(0.019)^{\wedge}$ \\
\hline Levels of $\mathrm{Cr} / \mathrm{Ni}$ & $0.543(0.266)$ & $-0.107(0.819)$ & $0.024(0.955)$ & $0.429(0.397)$ & $0.233(0.546)$ & $0.829(0.042)^{\wedge}$ \\
\hline
\end{tabular}

${ }^{\text {a }}$ Spearman's rank correlation coefficient while $p$-value is given in brackets; ${ }^{\wedge}$ Marginally significant difference

$(0.05<p<0.1)$ (Mann-Whitney non parametric test); ${ }^{\mathrm{b}}\left(n=4\right.$ roots); ${ }^{\mathrm{c}}\left(n=6\right.$ shoots); ${ }^{\mathrm{d}}$ ( $n=6$ leaves); ${ }^{\mathrm{e}}(n=6$ blossoms $)$.

Statistically significant positive and very strong correlations (Spearman's rho $=0.986$ ) were observed between the levels of $\mathrm{Cr}$ and $\mathrm{Ni}$ in shoots $(p$-value $=0.000)$ irrigated with a water concentration of $10,000 \mu \mathrm{g} / \mathrm{L}$, in leaves (Spearman's rho $=0.943$ ) irrigated with water concentration $0 \mu \mathrm{g} / \mathrm{L}$ $(p$-value $=0.005)$, and in blossoms (Spearman's rho $=0.829)$ irrigated with water concentration of $10,000 \mu \mathrm{g} / \mathrm{L}$ ( $p$-value $=0.042$ ). All the other correlations, as shown in Table 2, between the levels of chromium and nickel, can be characterized as positive or negative and not statistically significant since the level of statistical significance ( $p$-value) was over the limit of 0.05 . In roots and for the $500 \mu \mathrm{g} / \mathrm{L}$ irrigation line, there was no correlation at all between the levels of $\mathrm{Cr}$ and $\mathrm{Ni}$.

\subsection{Levels of $\mathrm{Cr}$ and $\mathrm{Ni}$ in Sunflower Oils}

The levels of $\mathrm{Cr}$ and $\mathrm{Ni}$ in the sunflower oils derived from the different irrigation water lines and a commercial available sample are presented in Table 3 . Three samples of sunflower oils were analyzed for each irrigation line using code names such as $0.1,0.2$, and 0.3 for the control irrigation line; 1.1, 1.2, and 1.3 for the $100 \mu \mathrm{g} / \mathrm{L}$ irrigation line, etc.

In all samples, the levels of Ni were found to be below both the LOD (Limit of detection) and LOQ (limit of quantification) values ( $\mathrm{LOD}=0.078 \mu \mathrm{g} / \mathrm{g}$ and $\mathrm{LOQ}=0.234 \mu \mathrm{g} / \mathrm{g}$ for nickel). The $\mathrm{Cr}$ levels could be quantified in all samples of the control irrigation line and for the 100, 1000, 5000, and 
$10,000 \mu \mathrm{g} / \mathrm{L}$ irrigation lines. In all samples of the $500 \mu \mathrm{g} / \mathrm{L}$ irrigation line, the levels of $\mathrm{Cr}$ were below $\mathrm{LOQ}(\mathrm{LOD}=0.008 \mu \mathrm{g} / \mathrm{g}, \mathrm{LOQ}=0.024 \mu \mathrm{g} / \mathrm{g}$ of sample for chromium).

Table 3. Levels of nickel and chromium in sunflower oils.

\begin{tabular}{|c|c|c|}
\hline \multirow{2}{*}{ Levels of $\mathrm{Ni}(\mathrm{II})$ and $\mathrm{Cr}(\mathrm{VI})$ in Irrigation Water $(\mu \mathrm{g} / \mathrm{L})$} & $\mathrm{Ni}(\mu \mathrm{g} / \mathrm{g})$ & $\mathrm{Cr}(\mu \mathrm{g} / \mathrm{g})$ \\
\hline & Average \pm SE & Average $\pm S E$ \\
\hline 0 & $<\mathrm{LOD}^{\mathrm{a}}$ & $0.053 \pm 0.02$ \\
\hline 100 & $<\mathrm{LOD}^{\mathrm{a}}$ & $0.025 \pm 0.01$ \\
\hline 500 & $<\operatorname{LOD}^{\mathrm{a}}$ & $<\mathrm{LOQ}^{\mathrm{b}}$ \\
\hline 1000 & $<\mathrm{LOD}^{\mathrm{a}}$ & $0.026 \pm 0.01$ \\
\hline 5000 & $<\mathrm{LOD}^{\mathrm{a}}$ & $0.026 \pm 0.02$ \\
\hline 10,000 & $<\mathrm{LOD}^{\mathrm{a}}$ & $0.028 \pm 0.02$ \\
\hline Market Sample & $<\mathrm{LOD}^{\mathrm{a}}$ & $<\mathrm{LOD}^{\mathrm{b}}$ \\
\hline
\end{tabular}

Average values \pm standard error, for three oil samples per irrigation line $(n=3)$. ${ }^{\text {a }}$ Limit of Detection $=$ $0.078\left(\mu \mathrm{g} / \mathrm{g}\right.$ of sample), Limit of Quantification $=0.234\left(\mu \mathrm{g} / \mathrm{g}\right.$ of sample) for Nickel; ${ }^{\mathrm{b}}$ Limit of Detection $=$ $0.008(\mu \mathrm{g} / \mathrm{g}$ of sample), Limit of Quantification $=0.024(\mu \mathrm{g} / \mathrm{g}$ of sample) for Chromium.

\subsection{Levels of Fatty Acids in Sunflower Oils}

The fatty acid profiles of sunflower oils are presented in the Table 4. As described before (Section 3.3), three samples of sunflower oils were analyzed for each irrigation line.

Table 4. Levels of fatty acids in sunflower oil.

\begin{tabular}{|c|c|c|c|c|c|c|}
\hline \multirow{3}{*}{ Fatty Acids } & \multicolumn{6}{|c|}{$\mathrm{Cr}(\mathrm{VI})$ and Ni (II) Concentration in Irrigation Water $(\mu \mathrm{g} / \mathrm{L})$} \\
\hline & 0 & 100 & 500 & 1000 & 5000 & 10,000 \\
\hline & Average \pm SE & Average \pm SE & Average \pm SE & Average \pm SE & Average \pm SE & Average \pm SE \\
\hline Palmitic acid (16:0) & $4.26 \pm 0.09$ & $3.89 \pm 0.71^{\mathrm{a}}$ & $4.05 \pm 0.37^{\mathrm{a}}$ & $3.54 \pm 0.91^{\mathrm{a}}$ & $3.56 \pm 0.44^{\mathrm{a}}$ & $4.36 \pm 0.17^{\mathrm{a}}$ \\
\hline Stearic Acid (18:0) & $1.28 \pm 0.87$ & $1.46 \pm 0.60^{\mathrm{a}}$ & $1.33 \pm 0.40^{\mathrm{a}}$ & $1.38 \pm 0.56^{\mathrm{a}}$ & $1.12 \pm 0.60^{\mathrm{a}}$ & $1.13 \pm 0.35^{\mathrm{a}}$ \\
\hline Oleic Acid (18:1 cis) & $36.95 \pm 2.11$ & $37.92 \pm 3.51^{\mathrm{a}}$ & $36.62 \pm 2.34^{\mathrm{a}}$ & $41.72 \pm 0.86^{\mathrm{b}}$ & $41.96 \pm 3.94^{b}$ & $42.05 \pm 2.46^{b}$ \\
\hline Linoleic Acid (18:2 cis) & $57.82 \pm 3.39$ & $56.74 \pm 2.72^{\mathrm{a}}$ & $58.00 \pm 2.12^{\mathrm{a}}$ & $53.36 \pm 0.64^{b}$ & $53.36 \pm 4.93^{b}$ & $52.46 \pm 2.29^{b}$ \\
\hline
\end{tabular}

Considerable amounts of palmitic acid $\left(16: 0, R_{t}=18.574\right)$, stearic acid $\left(18: 0, R_{t}=21.315\right)$, oleic acid $\left(18: 1\right.$ cis, $\left.R_{t}=21.799\right)$, and linoleic acid $\left(18: 2\right.$ cis, $\left.R_{t}=22.615\right)$ were detected in all samples. The levels of fatty acids in sunflower oils showed no statistical significant differences for the samples obtained from irrigation lines 0, 100, and 500 as depicted in Table 4.

For the levels of palmitic acid (16:0) (ranging from 3.54 to $4.36 \%$ of total fatty acids), no statistically significant differences ( $p$-value $>0.05$ ) were observed between the levels of the acid (16:0) in $0 \mu \mathrm{g} / \mathrm{L}$ and all irrigation water lines according to ANOVA analysis. Similarly, for the levels of stearic acid (18:0) (ranging from 1.12 to $1.46 \%$ of total fatty acids), no statistically significant differences ( $p$-value $>0.05$ ) were observed between the levels of the acid (18:0) in $0 \mu \mathrm{g} / \mathrm{L}$ and all irrigation water lines according to ANOVA analysis.

For oleic acid (18:1 cis), the obtained levels ranged from 36.62 to $42.05 \%$ of total fatty acids and no statistically significant differences ( $p$-value $>0.05$ ) were observed between $0 \mu \mathrm{g} / \mathrm{L}$ and $100 \mu \mathrm{g} / \mathrm{L}$ and $0 \mu \mathrm{g} / \mathrm{L}$ and $500 \mu \mathrm{g} / \mathrm{L}$, but statistically significant differences were observed between $0 \mu \mathrm{g} / \mathrm{L}$ and $1000 \mu \mathrm{g} / \mathrm{L}, 0 \mu \mathrm{g} / \mathrm{L}$ and $5000 \mu \mathrm{g} / \mathrm{L}$, and $0 \mu \mathrm{g} / \mathrm{L}$ and 10,000 $\mu \mathrm{g} / \mathrm{L}$ irrigation water lines.

As for linoleic acid (18:2 cis), the obtained levels ranged from 52.46 to $58.00 \%$ of total fatty acids and no statistically significant difference ( $p$-value $>0.05$ ) were observed between $0 \mu \mathrm{g} / \mathrm{L}$ and $100 \mu \mathrm{g} / \mathrm{L}$ and $0 \mu \mathrm{g} / \mathrm{L}$ and $500 \mu \mathrm{g} / \mathrm{L}$. However, statistically significant differences were observed between $0 \mu \mathrm{g} / \mathrm{L}$ 
and the higher irrigation water lines, i.e., between $0 \mu \mathrm{g} / \mathrm{L}$ and $1000 \mu \mathrm{g} / \mathrm{L}, 0 \mu \mathrm{g} / \mathrm{L}$ and $5000 \mu \mathrm{g} / \mathrm{L}$, and finally between $0 \mu \mathrm{g} / \mathrm{L}$ and 10,000 $\mu \mathrm{g} / \mathrm{L}$.

\section{Discussion}

The simulation of the contaminated areas of Asopos and Messapia [8] in the greenhouse and the study of tubers, antioxidant enzymes, and carotenoids, which can be used as biomarkers of heavy metal pollution [19], has been a main focus of our research work over the past few years. In order to measure the absorption of chromium and nickel and to study the tolerance of sunflower (Helianthus annuus) to bioaccumulate and extract these toxic metals, we cultivated sunflowers, trying to give an alternative solution to the polluted area of Asopos and Messapia [1,4]. The purpose of this study, as already mentioned above, is to investigate the ability of the sunflower (Helianthus annuus) and specifically of the roots, shoots, leaves, and blossoms to bioaccumulate chromium and nickel and furthermore to assess the quantification of these two metals in the sunflower oil and the safety of the obtained oil for human consumption.

The maximum absorption of chromium in shoots, leaves, and blossoms was mainly observed from the higher irrigation line $(10,000 \mu \mathrm{g} / \mathrm{L})$. It is important to note that according to our results, chromium stayed in the roots of the sunflower, while smaller concentrations were noticed in shoot, leaves, and blossoms by comparison [10]. Chromium is usually retained in vacuoles and cell walls of the root cells with low mobility within the plant. However, increased concentrations of $\mathrm{Cr}$ have been reported in the leaves of plants being grown in soils irrigated with different concentrations of $\mathrm{Cr}$, but the transfer mechanism remains unknown [20]. After $\mathrm{Cr}$ is absorbed by roots from nutrient solution as $\mathrm{Cr}$ (III) or $\mathrm{Cr}$ (VI), it is poorly translocated elsewhere and largely retained in the root [10].

The highest absorption of nickel in the experiment for roots, shoots, and leaves of the sunflower was also observed from the last irrigation line $(10,000 \mu \mathrm{g} / \mathrm{L})$. The concentration of nickel absorbed by the roots was higher compared to that of shoots, leaves, and blossoms. Generally, the total amounts of chromium and nickel absorbed by the plant remained in the roots despite the fact that there were six different irrigation lines with different concentrations of $\mathrm{Cr}$ (VI) and $\mathrm{Ni}$ (II). In similar studies to ours, the higher absorbance of $\mathrm{Ni}$ was recorded in stems [21], whereas $\mathrm{Ni}$ in the leaves of sunflower have been observed to be selectively distributed to key points of the sheet (mesophyll) of the plant [17].

Sunflower's capacity to extract heavy metals has been compared to Indian mustard and rapeseed, and it was found that sunflower can absorb $\mathrm{Cd}, \mathrm{Ni}, \mathrm{Pb}$, and $\mathrm{Zn}$ more extensively. These results indicated that sunflower can grow on soil contaminated with $\mathrm{Cr}, \mathrm{Cu}$, and $\mathrm{Zn}$, and it can also accumulate large amounts of $\mathrm{Zn}$ [22]. Sunflower is relatively resistant to high $\mathrm{Zn}$ soil concentrations; therefore, it can be used for $\mathrm{Zn}$ phytoextraction of moderately contaminated soil (approximately $200 \mathrm{mg} \mathrm{Zn} \mathrm{kg}{ }^{-1}$ soil) [23].

In the phytoextraction technology, the chosen plants should be able to absorb high amounts of heavy metals and translocate them from roots to shoots, leaves, and blossoms [13,14]. Many plants do not have the ability to achieve this transfer, for instance, plants with low biomass can hyper-accumulate metals in roots but they are not able to transfer them to other plant parts [24]. Roots were the main accumulation site for many heavy metals such as $\mathrm{Pb}$. After four weeks, approximately $80-87 \%$ of the total $\mathrm{Pb}$ uptake was localized in plant roots with only $13-20 \%$ translocated to the aboveground plant parts. Their results indicated that sunflower, compared to other plant species (N. tabacum and $V$. zizanioides), best met prerequisites for a $\mathrm{Pb}$-accumulating plant for use in remediating a $\mathrm{Pb}$ contaminated site [24]. Lead in the roots of sunflower reached $3.5 \mathrm{mg} / \mathrm{kg}$ and $\mathrm{Zn}$ reached $17.7 \mathrm{mg} / \mathrm{kg}$. The accumulation of metals in the stems varied within a wide range and also depended on the type of crop and the element that was examined. Considerably lower values were ascertained in the leaves of sunflower. Lead in the leaves of sunflower reached $35.6 \mathrm{mg} / \mathrm{kg}$. In general, the distribution of the heavy metals in the plant organs had a selective character [25]. The highest concentration of toxic metals was found in the roots of corn and sunflower (up to 1000 times higher than that of controls grown on non-contaminated soil). Relatively high concentrations of toxic metals were determined also 
in stems and leaves (10 times higher than in that of controls) [26]. Chromium, nickel, and lead showed similar trends. Respectively, the highest amounts were found in plant roots (for $\mathrm{Cr} 6.83 \mathrm{mg} / \mathrm{kg}$, for $\mathrm{Ni} 5.04 \mathrm{mg} / \mathrm{kg}$, and for $\mathrm{Pb} 7.76 \mathrm{mg} / \mathrm{kg}$ ); sunflower has shown a higher ability to accumulate these elements than maize [27]. Cadmium accumulation in herbs was similar to those for $\mathrm{Cr}, \mathrm{Ni}$, and $\mathrm{Pb}$, whereas a significantly higher amount of chromium was found in sunflower roots $(7.02 \mathrm{mg} / \mathrm{kg}$ ) [27]. In comparison to the other species, vetiver is the most tolerant to $\mathrm{Pb}$, followed by castor bean, sunflower, and common buckwheat [28].

According to our statistical analysis, the differences between the irrigation lines with $\mathrm{Cr}(\mathrm{VI})$ and $\mathrm{Ni}$ (II) and the chromium and nickel levels in roots, shoots, leaves, and blossoms, in "two by two" comparison, were statistically significant, and there was also a positive strong correlation, which can be characterized as statistically significant, between them.

Finally taking into account the sunflower oil results, it can be seen that the concentration of nickel was below the limit of detection and quantification. On the other hand, the concentrations of $\mathrm{Cr}$ were in the range of 0.029 to $0.071 \mu \mathrm{g} / \mathrm{g}$ in different irrigation water lines. Because of the fact that nickel levels in oils were below LOD or LOQ in all oil samples and due to the limited data obtained for $\mathrm{Cr}$ levels in oils, any statistical analysis for the levels of $\mathrm{Cr}$ and $\mathrm{Ni}$ in oils was not feasible. Our data strongly suggest, though, that the irrigation of plants with polluted water did not result in increased levels of either $\mathrm{Ni}$ or $\mathrm{Cr}$ in the obtained sunflower oil samples.

In previous research [29], the concentration of $\mathrm{Cr}$ was found to be below the limit of detection, and the concentrations of $\mathrm{Ni}$ and other selected metals were in a range of 0.1 to $1.5 \mu \mathrm{g} / \mathrm{g}$ and were comparable to other edible oils including sunflower oil; pumpkin seed oil samples contained higher amounts of $\mathrm{Ni}(6.1 \mu \mathrm{g} / \mathrm{g})$. The levels of nickel in a comparison study were also not detected in sunflower oil and were lower than the LODs [30]. The presence of four elements, $\mathrm{Cr}, \mathrm{Cu}, \mathrm{Fe}$, and $\mathrm{Mn}$, was observed in all types of oils, and in the case of $\mathrm{Cr}$, its concentration was higher in the vegetable oils other than olive oils. Nickel was also lower than the LODs [31].

The estimation of the risk to human health from the presence of chromium in food, particularly in vegetables, according to European Food Safety Authority (EFSA) is $0.3 \mathrm{mg} / \mathrm{kg}$ b.w. per day for $\mathrm{Cr}$ from the lowest Non-Observed Adverse Effect Level (NOAEL) identified in an (National Toxicology Program) NTP chronic oral toxicity study in rats [32]. The consumption of sunflower oil per day is approximately $20 \mathrm{~mL}$ so we can conclude that the oil, obtained in this study, is safe for consumption. Plant based edible oils, such as sunflower oil, are extensively used in daily life, and their quality has received great attention due to their influence on human nutrition and health. Those reasons led us to investigate further the lipid profile of the sunflower oil and, as mentioned above, considerable amounts of palmitic acid (16:0), stearic acid (18:0), oleic acid (18:1 cis), and linoleic acid (18:2 cis) were detected in all oil samples. The levels of palmitic (16:0) and stearic (18:0) acids exhibited no statistical significant differences between different irrigation water lines. The statistical analysis for oleic (18:1 cis) and linoleic (18:2 cis) acids showed a statistically significant increase and decrease respectively, between $0 \mu \mathrm{g} / \mathrm{L}$ and $1000 \mu \mathrm{g} / \mathrm{L}, 5000 \mu \mathrm{g} / \mathrm{L}$, and 10,000 $\mu \mathrm{g} / \mathrm{L}$.

\section{Conclusions}

Given that both $\mathrm{Cr}$ and $\mathrm{Ni}$ tend to have an identical tendency to be phytoaccumulated, with the highest percentage concentrating in the roots [33], we have demonstrated here the ability of sunflower to phytoaccumulate significant amounts of these toxic metals. We have shown previously that the presence of $\mathrm{Ni}$ and $\mathrm{Cr}$ in Asopos River and Messapia areas causes cross contamination of the food chain $[1,4]$. The ability of the sunflower to bio remediate this water pollution is a promising technology which can give farmers an alternative agriculture species for farming, providing a final product (i.e., sunflower oil) that would not be cross-contaminated by harmful heavy metals. Also it is worth pointing out that due to the lipids profile and the results of chromium and nickel absorption, sunflower oil after a cleaning and removal process could be safe for consumption or for use as biofuel or other applications. 
According to EFSA recommendations on chromium intake ( $0.3 \mathrm{mg} / \mathrm{kg}$ b.w. per day) [32], and taking into consideration the daily consumption of sunflower oil $(20 \mathrm{~mL})$, our results validate the consumption of the oil as safe. Sunflower could also be used for fodder, technical purposes, and biodiesel whilst farmers would be able to decrease negative environmental consequences in the area.

Supplementary Materials: The following are available online at www.mdpi.com/2304-8158/6/7/51/s1, Figure S1: Levels of: (a) chromium and (b) nickel as determined by Atomic Absorption Spectroscopy (AAS) in roots, shoots, leaves, and blossoms in different irrigation lines. Table S1: Two by two comparisons of $\mathrm{Cr}$ and $\mathrm{Ni}$ between different concentrations in irrigation water.

Acknowledgments: This research did not receive any specific grant from funding agencies in the public, commercial, or not-for-profit sectors. The financial contribution of the Department of Biological Sciences, University of Limerick towards covering the costs to publish in open access is acknowledged.

Author Contributions: N.S.T. and I.Z. conceived and designed the experiments; V.S., V.A., S.S., M.G.K., and S.A. performed the experiments; V.S., V.A., S.S., and I.Z. analyzed the data; V.S., S.S., and I.Z. wrote the paper.

Conflicts of Interest: The authors declare no conflict of interest.

\section{References}

1. Stasinos, S.; Zabetakis, I. The uptake of nickel and chromium from irrigation water by potatoes, carrots and onions. Ecotoxicol. Environ. Saf. 2013, 91, 122-128. [CrossRef] [PubMed]

2. Flemotomou, E.; Molyviatis, T.; Zabetakis, I. The Effect of Trace Elements Accumulation on the Levels of Secondary Metabolites and Antioxidant Activity in Carrots, Onions and Potatoes. Food Nutr. Sci. 2011, 2, 1071-1076. [CrossRef]

3. Gerhardt, K.E.; Huang, X.D.; Glick, B.R.; Greenberg, B.M. Phytoremediation and rhizoremediation of organic soil contaminants: Potential and challenges. Plant Sci. 2009, 176, 20-30. [CrossRef]

4. Kirkillis, C.G.; Pasias, I.N.; Miniadis-Meimaroglou, S.; Thomaidis, N.S.; Zabetakis, I. Concentration Levels of Trace Elements in Carrots, Onions, and Potatoes Cultivated in Asopos Region, Central Greece. Anal. Lett. 2012, 45, 551-562. [CrossRef]

5. Dheeba, B.A.; Sampathkumar, P. Comparative Study on the Phytoextraction of five Common Plants against Chromium Toxicity. Orient. J. Chem. 2012, 28, 867-879. [CrossRef]

6. Kokyo, O.; Tao, L.; Hongyan, C.; Xieying, H.; Shinichi, Y. Study on Tolerance and Accumulation Potential of Biofuel Crops for Phytoremediation of Heavy Metals. Int. J. Environ. Sci. Dev. 2013, 4, 152-156. [CrossRef]

7. Souza, L.A.; Piotto, F.A.; Nogueirol, R.C.; Azevedo, R.A. Use of non-hyperaccumulator plant species for the phytoextraction of heavy metals using chelating agents. Sci. Agric. 2013, 70, 290-295. [CrossRef]

8. Stasinos, S.; Nasopoulou, C.; Tsikrika, C.; Zabetakis, I. The Bioaccumulation and Physiological Effects of Heavy Metals in Carrots, Onions, and Potatoes and Dietary Implications for Cr and Ni: A Review. J. Food Sci. 2014, 79, R765-R780. [CrossRef] [PubMed]

9. Chen, C.; Huang, D.; Liu, J. Functions and toxicity of nickel in plants: Recent advances and future prospects. CLEAN Soil Air Water 2009, 37, 304-313. [CrossRef]

10. Zayed, A.M.; Terry, N. Chromium in the environment: Factors affecting biological remediation. Plant Soil 2003, 249, 139-156. [CrossRef]

11. Lotfy, S.M.; Mostafa, A.Z. Phytoremediation of contaminated soil with cobalt and chromium. J. Geochem. Explor. 2014, 144, 367-373. [CrossRef]

12. Mei, B.; Puryear, J.D.; Newton, R.J. Assessment of $\mathrm{Cr}$ tolerance and accumulation in selected plant species. Plant Soil 2002, 247, 223-231. [CrossRef]

13. Ton, S.S.; Lee, M.W.; Yang, Y.H.; Hoi, S.K.; Cheng, W.C.; Wang, K.S.; Chang, H.H.; Chang, S.H. Effects of Reductants on Phytoextraction of Chromium (VI) by Ipomoea aquatica. Int. J. Phytoremediat. 2014, 17, 429-436. [CrossRef] [PubMed]

14. Kötschau, A.; Büchel, G.; Einax, J.W.; von Tümpling, W.; Merten, D. Sunflower (Helianthus annuus): Phytoextraction capacity for heavy metals on a mining-influenced area in Thuringia, Germany. Environ. Earth Sci. 2014, 72, 2023-2031. [CrossRef]

15. Nasopoulou, C.; Stamatakis, G.; Demopoulos, C.A.; Zabetakis, I. Effects of olive pomace and olive pomace oil on growth performance, fatty acid composition and cardio protective properties of gilthead sea bream (Sparus aurata) and sea bass (Dicentrarchus labrax). Food Chem. 2011, 129, 1108-1113. [CrossRef] [PubMed] 
16. Hervé, A. Bonferroni and Sidak Corrections for Multiple Comparisons; Encyclopedia of Measurement and Statistics; Sage: Thousand Oaks, CA, USA, 2007.

17. Kötschau, A.; Büchel, G.; Einax, J.W.; Fischer, C.; von Tümpling, W.; Merten, D. Mapping of macro and micro elements in the leaves of sunflower (Helianthus annuus) by Laser Ablation-ICP-MS. Microchem. J. 2013, 110, 783-789. [CrossRef]

18. Shanker, A.K.; Cervantes, C.; Loza-Tavera, H.; Avudainayagam, S. Chromium toxicity in plants. Environ. Int. 2005, 31, 739-753. [CrossRef] [PubMed]

19. Andrianos, V.; Stoikou, V.; Tsikrika, K.; Lamprou, D.; Stasinos, S.; Proestos, C.; Zabetakis, I. Carotenoids and Antioxidant Enzymes as Biomarkers of the Impact of Heavy Metals in food Chain. Curr. Res. Nutr. Food Sci. 2016, 4, 15-24. [CrossRef]

20. Davies, F.T.; Puryear, J.D.; Newton, R.J.; Egilla, J.N.; Grossi, J.A.S. Mycorrhizal fungi enhance accumulation and tolerance of chromium in sunflower (Helianthus annuus). Plant Physiol. Biochem. 2001, 158, 777-786. [CrossRef]

21. Bosiacki, M.; Wojciechowska, E. Phytoextraction of Nickel by Selected Ornamental Plants. Ecol. Chem. Eng. 2012, 19, 331-345. [CrossRef]

22. Shaheen, S.M.; Rinklebe, J. Phytoextraction of potentially toxic elements by Indian mustard, rapeseed, and sunflower from a contaminated riparian soil. Environ. Geochem. Health 2015, 37, 953-967. [CrossRef] [PubMed]

23. Zalewska, M.; Nogalska, A. Phytoextraction potential of sunflower and white mustard plants in zinc-contaminated soil. Chilean J. Agric. Res. 2014, 74, 485-489. [CrossRef]

24. Boonyapookana, B.; Parkpian, P.; Techapinyawat, S.; DeLaune, R.D.; Jugsujinda, A. Phytoaccumulation of lead by sunflower (Helianthus annuus), tobacco (Nicotiana tabacum), and vetiver (Vetiveria zizanioides). J. Environ. Sci. Health. A Tox. Hazard. Subst. Environ. Eng. 2005, 40, 117-137. [CrossRef]

25. Angelova, V.; Ivanova, R.; Ivanov, K. Heavy metal accumulation and distribution in oil crops. Commun. Soil Sci. Plant Anal. 2004, 35, 2551-2566. [CrossRef]

26. Soudek, P.; Petrová, S.; Benešová, D.; Vaněk, T. Phytoextraction of toxic metals by sunflower and corn plants. J. Food Agric. Environ. 2010, 8, 383-390.

27. Kacálková, L.; Tlustoš, P.; Száková, J. Chromium, Nickel, Cadmium, and Lead Accumulation in Maize, Sunflower, Willow, and Poplar. Pol. J. Environ. Stud. 2014, 23, 753-761.

28. Alves, J.C.; de Souza, A.P.; Pôrto, M.L.A.; Fontes, R.L.F.; Arruda, J.L.F. Potential of sunflower, castor bean, common buckwheat and vetiver as lead phytoaccumulators. Rev. Bras. Eng. Agric. Ambient. 2016, 20, 243-249. [CrossRef]

29. Cindric, I.J.; Zeiner, M.; Steffan, I. Trace elemental characterization of edible oils by ICP-AES and GFAAS. Microchem. J. 2007, 85, 136-139. [CrossRef]

30. Gunduz, S.; Akman, S. Investigation of trace element contents in edible oils sold in Turkey using microemulsion and emulsion procedures by graphite furnace atomic absorption spectrophotometry. LWT Food Sci. Technol. 2015, 64, 1329-1333. [CrossRef]

31. Llorent-Martinez, E.J.; Ortega-Barrales, P.; Fernandez-De Cordova, M.L.; Dominguez-Vidal, A.; Ruiz-Medina, A. Investigation by ICP-MS of trace element levels in vegetable edible oils produced in Spain. Food Chem. 2011, 127, 1257-1262. [CrossRef] [PubMed]

32. EFSA Panel on Contaminants in the Food Chain (CONTAM). Scientific Opinion on the Risks to Public Health Related to the Presence of Chromium in Food and Drinking Water. 2014. Available online: https: / / www.efsa.europa.eu/en/efsajournal/pub/3595 (accessed on 14 June 2017).

33. Eissa, M.A.; Ghoneim, M.F.; El-gharably, G.A.; El-razek, M.A. Phytoextraction of nickel, lead and cadmium from metals contaminated soils using different field crops and EDTA. World Appl. Sci. J. 2014, 32, 1052. [CrossRef]

(C) 2017 by the authors. Licensee MDPI, Basel, Switzerland. This article is an open access article distributed under the terms and conditions of the Creative Commons Attribution (CC BY) license (http:/ / creativecommons.org/licenses/by/4.0/). 